\title{
Izborni proces u Bosni i Hercegovini: hibridni spoj modernih i zastarjelih rješenja
}

\author{
Damir Arnaut* \\ Poslanik u Predstavničkom domu \\ Parlamentarne skupštine Bosne i Hercegovine, \\ BA, MA., Juris Doctor, University of California, Berkeley, \\ Damir.Arnaut@parlament.ba
}

\section{Uvod}

Izborni zakon Bosne i Hercegovine je jedini državni zakon čije je usvajanje eksplicitno propisano Ustavom Bosne i Hercegovine. ${ }^{1}$ U skladu s tim istim Ustavom, prvi izbori nakon rata u Bosni i Hercegovini održani su 1996. godine, prema odredbama propisanim Aneksom 3. Daytonskog mirovnog sporazuma $^{2}$, u organizaciji OSCE-a, a što se nastavilo i u naredna dva izborna ciklusa (1998. i 2000). Prvi Izborni zakon BiH usvojen je 2001. godine ${ }^{3}$, te je u proteklih dvadeset godina pretrpio brojne izmjene i dopune. ${ }^{4}$ Pored ovih legislativnih aktivnosti ${ }^{5}$, na tekst Izbornog zakona BiH uticale su i Odluke Ustavnog suda $\mathrm{BiH}$, koji je određene odredbe stavio van snage nakon što ih je proglasio neustavnim. ${ }^{6}$

I pored tih čestih intervencija na osnovni tekst, izmjene strateške prirode su umnogome izostale. Većina navedenih intervencija bile su reaktivne prirode, poput implementacije odluka Ustavnog suda $\mathrm{BiH}$, usaglašavanja sa drugim zakonima, preciziranja terminologije, te rješavanja administrativnih pitanja. Inicijative suštinske prirode su, šta više, primarno dolazile iz poslaničkih,

\footnotetext{
${ }^{*}$ Izneseni stavovi su lični i ne odražavaju nužno stavove Parlamentarne skupštine Bosne i Hercegovine ${ }^{1}$ Član IV.2 i član V.1 Ustava Bosne i Hercegovine (Aneksa 4. Daytonskog mirovnog sporazuma) eksplicitno nalažu da će Parlamentarna skupština BiH usvojiti ,izborni zakon“. Jedine tri druge odredbe Ustava BiH koje nalažu donošenje konkretnih zakona ne preciziraju nazive tih zakona (član II.4, član III.2.d), član IV.4.a).

${ }^{2}$ Član IV.2 Ustava BiH.

3 "Službeni glasnik BiH“" br. 23/01.

4 "Službeni glasnik BiH" br. 23/01, 7/02, 9/02, 20/02, 25/02, 4/04, 20/04, 25/05, 52/05, 65/05, 77/05, 11/06, 24/06, 32/07, 33/08, 37/08, 32/10, 18/13, 7/14, 31/16 i 41/20.

${ }^{5}$ Uključujući zakone nametnute od strane Visokog predstavnika (OHR)

${ }^{6}$ „Službeni glasnik BiH“ br. 15/12.
} 
mahom opozicionih, krugova, umjesto od Vijeća ministara BiH, što je dodatno umanjilo mogućnosti za njihovo usvajanje, ali i demonstriralo nedostatak volje vladajućih struktura za značajnije izmjene.

Trenutno postoji nekoliko presuda Evropskog suda za ljudska prava ${ }^{7}$, kao i jedna odluka Ustavnog suda $\mathrm{BiH}^{8}$, koje nalažu izmjene Izbornog zakona, a koje još uvijek nisu implementirane. Kada su u pitanju presude Evropskog suda, one se odnose na diskriminaciju kod izbora članova Predsjedništva BiH i delegata u Domu naroda Parlamentarne skupštine BiH, dok se navedena odluka Ustavnog suda BiH tiče neproporcionalne zastupljenosti u Domu naroda Parlamenta Federacije BiH.

Za potrebe implementacije prve grupe predmeta, pored izmjena Izbornog zakona, neophodne su i izmjene Ustava $\mathrm{BiH}$ jer je navedena diskriminacija propisana odredbama tog Ustava. Odluka Ustavnog suda BiH, s druge strane, se teoretski može implementirati isključivo kroz izmjene Izbornog zakona. Uzimajući, međutim, u obzir činjenicu da ta odluka nalaže zastupljenost konstitutivnih naroda proporcionalnu njihovoj populaciji u različitim kantonima, a da Ustav Federacije BiH nalaže po jednog od ukupno 17 pripadnika svakog konstitutivnog naroda iz svakog od 10 kantona u kojem je barem jedan pripadnik izabran u kantonalnu skupštinu, ovu odluku je u praksi gotovo nemoguće implementirati bez pratećih izmjena Ustava Federacije $\mathrm{BiH}$.

Izmjene Izbornog zakona koje ove presude i odluka nalažu su najzastupljenije u javnom i političkom diskursu, te su i najčešći predmet akademskih radova na temu izbornog zakonodavstva u Bosni i Hercegovini. Dijelom i zbog te fokusiranosti političkih elita, ali i akademske zajednice, na navedene teme, druga pitanja od suštinskog značaja za unapređenje Izbornog zakona $\mathrm{BiH}$ često budu zanemarena.

Ovaj rad će se, stoga, usredotočiti na one izmjene koje su Bosni i Hercegovini potrebne kako bi unaprijedila svoj izborni sistem, a koje se pojavljuju i u drugim državama koje prakticiraju višestranačku demokratiju. Naime, dok su teme iz navedenih presuda i odluka Evropskog suda i Ustavnog suda BiH specifične za Bosnu i Hercegovinu, te kao takve nisu pogodne za potrebe komparativnog pristupa, nekoliko drugih pitanja je podložno uporednom pristupu s ciljem razmatranja poboljšanja izbornog postupka u Bosni i Hercegovini.

\footnotetext{
${ }^{7}$ Pilav v. Bosnia and Herzegovina, Presuda od 9. juna 2016, Sejdic-Finci v. Bosnia and Herzegovina, Presuda od 22. decembra 2009., Zornić v. Bosnia and Herzegovina, Presuda od 15. jula 2014., Šlaku v. Bosnia and Herzegovina, Presuda od 26. maja 2016.

${ }^{8}$ Odluka o dopustivosti i meritumu, U-23/14, 1. decembar 2016.
} 


\section{Prednosti i nedostaci izbornog procesa u Bosni i Hercegovini}

\section{Napredne vrijednosti izbornog sistema Bosne i Hercegovine}

Navedenih dvadeset godina primjene Izbornog zakona BiH pokazalo je da su određena rješenja izuzetno dobra, ali da su suštinske izmjene neophodne u nekim drugim poljima. Primjera radi, postojanje Centralne izborne komisije, kao stručnog, nestranačkog tijela sa širokim ovlastima koje u konačnici odlučuje većinom glasova bez bilo kakve potrebne etničke ili entitetske kvote je dobrodošla pojava u Bosni i Hercegovini. Činjenica da poslanički mandat pripada izabranom pojedincu, a ne političkoj stranci, značajno unapređuje demokratski kapacitet, te predstavlja pozitivan primjer za mnogo starije demokratije. Šta više, automatska, odnosno pasivna, registracija glasača putem CIPS sistema prilikom izdavanja lične karte predstavlja jedan od najnaprednijih načina u svijetu za osiguranje prava svih građana da glasaju. ${ }^{9}$ Konačno, obavezna spolna zastupljenost od minimalno $40 \%$ na kandidatskim listama ${ }^{10}$ predstavlja pozitivnu praksu čak i u poređenju sa najrazvijenijim demokratskim društvima.

\section{Prostor za kratkroročno unapređenje Izbornog zakona BiH i izbornog sistema}

Istovremeno, Bosna i Hercegovina zaostaje za mnogim zemljama u svijetu na brojnim poljima, poput nemogućnosti ranog glasanja ili glasanja poštom, ${ }^{11}$ nedostatka nadležnosti Centralne izborne komisije da provjerava istinitost informacija navedenim u imovinskim kartonima izabranih zvaničnika, ili pak pretjerane dužine trajanja izbornog procesa u odnosu na trajanje same izborne kampanje. ${ }^{12}$ Također, osim restruktuiranja izbornih jedinica za izbore u

\footnotetext{
${ }^{9}$ Poređenja radi, u Sjedinjenim Američkim Državama, sve savezne države osim Sjeverne Dakote nalažu aktivnu registraciju, zbog čega oko $24 \%$ građana SAD-a nisu registrovani za glasanje. Vidjeti The Pew Center on the States, Inaccurate, Costly and Inefficient, Election Initiatives Issue Brief, Feb. 2012., https://www.pewtrusts.org/ /media/legacy/uploadedfiles/pcs_assets/2012/PewUpgradingVoterRegistrationpdf.pdf . Međutim, zbog izuzetno brojnog iseljeništva, koje u velikom broju zadržava/obnavlja ličnu kartu, ovaj sistem daje pogrešnu sliku o stvarnom procentu izlaznosti na izbore.

${ }^{10}$ Izborni zakon $\mathrm{BiH}$, čl. 4.19.

${ }^{11}$ Glasanje poštom omogućeno je, uz aktivnu registraciju, za građane koji žive u inostranstvu, ali nije dozvoljeno građanima koji žive u Bosni i Hercegovini, a nisu prisutni u općini svog prebivališta na dan izbora.

${ }^{12}$ Izborni proces traje pet mjeseci od dana raspisivanja izbora do izbornog dana, dok je za izbornu kampanju ostavljeno samo zadnjih 30 dana tog izbornog procesa. Istovremeno, tokom prva četiri mjeseca izbornog procesa nije dozvoljeno plaćeno političko oglašavanje niti vođenje izborne kampanje, iako se stranke u tom periodu registruju za izbore, predaju kandidatske liste i slično.
} 
Narodnu skupštinu RS nakon popisa stanovništva, izostalo je slično restruktuiranje za potrebe izbora u Parlamentarnu skupštinu BiH iz oba entiteta, kao i za Parlament Federacije BiH. S tim u vezi, vrijednost glasa značajno varira u različitim izbornim jedinicima, te u nekim slučajevima postoje izuzetno visoka odstupanja.

Primjera radi, dok iz izborne jedinice koja obuhvata područje Kantona Sarajevo i Bosansko-podrinjskog kantona dolazi jedan državni poslanik na preko 110.000 glasača, taj omjer je u izbornoj jedinici na području Hercegovačko-neretvanskog i Zapadno-hercegovačkog kantona jedan poslanik na 89.000 glasača, što predstavlja odstupanje od preko $20 \%{ }^{13}$ Razlika je još značajnija u izbornim jedinicama Parlamenta Federacije $\mathrm{BiH},{ }^{14}$ gdje, primjera radi, u izbornoj jedinici 12 koja obuhvata područje Livanjskog kantona dolazi jedan poslanik na oko 21.000 glasača, dok u izbornoj jedinici 4, na području Tuzlanskog kantona jedan poslanik predstavlja čak 34.000 glasača, razlika od preko $60 \% .^{15}$

Ovakav nesrazmjer nesumnjivo krši prava značajnog broja građana Bosne i Hercegovine na jednakost po pitanju zastupljenosti. Venecijanska komisija je jasno istakla da je pravo na jednakost glasa „duboko povezana sa općim principom izborne reprezentativne demokratije“, ${ }^{16}$ te da taj princip nalaže da svi građani mogu uticati na političke odluke putem svojih zastupnika koji su izabrani na općim, slobodnim, direktnim i tajnim izborima, „,koristeći univerzalni princip 'jedan čovjek, jedan glas'“. ${ }^{17}$

Međunarodni standardi ne zabranjuju posebne mjere koje osiguravaju minimalnu zastupljenost određenih grupa, etničkih, jezičkih, regionalnih ili drugih, ${ }^{18}$ i koje mjere se uostalom primjenjuju na svim nivoima u Bosni i Hercegovini. ${ }^{19}$ Iznad navedeni nesrazmjer, međutim, nije rezultat bilo kakvih

\footnotetext{
${ }^{13} \mathrm{CIK}$ BiH, Rezultati izbora, Opći izbori 2018, http://www.izbori.ba/Default.aspx?CategoryID=916 \&Lang $=3$.

${ }^{14}$ Izborni zakon BiH, čl. 20.13.

${ }^{15} \mathrm{Ibid} . \mathrm{iCIKBiH}$, Rezultatiizbora, Općiizbori2018, http://www.izbori.ba/Default.aspx?CategoryID=916 \&Lang $=3$.

${ }^{16}$ European Commission on Democracy through Law (Venice Commission), Report on Constituency Delineation and Seat Allocation, Study No. 873/2017, Strasbourg, 12. dec 2017, str. 4.

${ }^{17}$ Ibid.

${ }^{18}$ Ibid., str. 4-5.

${ }^{19}$ Ustavi Bosne i Hercegovine, oba entiteta, kao i Izborni zakon BiH, garantuju minimalnu zastupljenost (najmanje četiri) pripadnika konstitutivnih naroda u Predstavničkom domu Parlamenta FBiH, odnosno Narodnoj skupštini RS, jednaku zastupljenost svakog konstitutivnog naroda u Domu naroda Parlamentarne skupštine $\mathrm{BiH}$, Domu naroda Parlamenta FBiH, odnosno Vijeću naroda RS, minimalnu i maksimalnu zastupljenost poslanika i delegata u Parlamentarnoj skupštini BiH koji se biraju, odnosno delegiraju, iz jednog i drugog entiteta, i slično.
} 
posebnih mjera kako bi se takva zastupljenost osigurala, već do tog nesrazmjera dolazi isključivo zbog činjenice da odredbe Izbornog zakona BiH koje nalažu restruktuiranje izbornih jedinica nakon provedenog popisa stanovništva.

Da se radi o principu utemeljenom u nacionalnim i međunarodnim instrumentima i presudama pokazuje činjenice da je Vrhovni sud SAD-a još 1962. odlučio da građani imaju pravo da biraju svoje predstavnike po principu ,jedan čovjek, jedan glas“", te da se ne radi o diskrecionom pravu zakonodavnih organa da osiguraju ili ne osiguraju takve izborne jedinice. ${ }^{20}$ Ova odluka je konkretizovana kroz dva naknadna slučaja, u kojim je Vrhovni sud odlučio da ${ }^{21}$ izborne jedinice za Predstavnički dom Kongresa SAD-a, ${ }^{22}$ odnosno zakonodavna tijela saveznih država, trebaju imati ,približno jednak broj stanovnika“".23

Šta više, Venecijanska komisija je jasno istakla da je pravo na jednaku vrijednost glasa garantovano brojnim međunarodnim mehanizmima, poput Međunarodnog pakta o građanskim i političkim pravima, Opće deklaracije o ljudskim pravima UN-a, Protokola 1 na Evropsku konvenciju o ljudskim pravima, Pravila dobre prakse u izbornim stvarima Venecijanske komisije, te brojnih drugih. ${ }^{24}$

Ovaj problem, stoga, predstavlja grubo kršenje osnovnih prava značajnog broja građana Bosne i Hercegovine, a rješenje za isti je već precizirano Izbornim zakonom $\mathrm{BiH}$, te isključivo zahtijeva implementaciju u vidu restrukturiranja postojećih izbornih jedinica kako bi broj glasača po izabranom zastupniku bio približno isti u svakoj od tih izbornih jedinica.

Konačno, iako je glasačima u Brčko distriktu omogućeno da se opredijele za entitetsko državljanstvo Federacije BiH ili Republike Srpske za potrebe glasanja za Parlamentarnu skupštinu BiH, Parlament Federacije BiH ili Narodnu skupštinu Republike Srpske, ${ }^{25}$ glasači koji se opredijele za državljanstvo Federacije $\mathrm{BiH}$ ne mogu glasati na izborima za bilo koju kantonalnu skupštinu, čime im je onemogućen izbor u Dom naroda Parlamenta Federacije $\mathrm{BiH} .{ }^{26}$ Ovo pitanje, međutim, nije moguće riješiti isključivo kroz izmjene Izbornog zakona $\mathrm{BiH}$, već isto zahtijeva intervencije na Ustav Federacije $\mathrm{BiH}$.

\footnotetext{
${ }^{20}$ Baker v. Carr, 369 U.S. 186 (1962).

${ }^{21}$ Reynolds v. Sims, 377 U.S. 533 (1964).

${ }^{22}$ Wesberry v. Sanders, 376 U.S. 1 (1964).

${ }^{23}$ Ibid.

${ }^{24}$ Venice Commission Report, supra n. 16, str. 11.-13.

${ }^{25}$ Izborni zakon BiH, čl. 10.2, 11.3 i 18.2.

${ }^{26}$ Izborni zakon BiH, čl. 10.10.
} 


\section{Potrebne izmjene izbornog zakonodavstva sa stanovišta komparativne prakse}

Kada su, međutim, u pitanju strateški nedostaci ili nepotpunosti Izbornog zakona, praksa u Bosni i Hercegovini ukazuje četiri pitanja od primarne važnosti: 1. Nedostatak instituta vanrednih izbora, 2. Nedostatak drugog kruga glasanja, 3. Nizak izborni cenzus, te 4. Nedostatak modernih tehnologija za glasanja i brojanje glasova. Ova četiri pitanja će biti razmotrena prema navedenom redoslijedu.

\section{Vanredni izbori za izvanredne situacije}

Institut ili mogućnost vanrednih izbora ${ }^{27}$ predstavlja redovnu praksu u gotovo svim parlamentarnim demokratijama u svijetu, uključujući u Westminsterskom sistemu, ${ }^{28}$ dok je manje prisutan u jakim predsjedničkim sistemima. S tim u vezi, vanredni izbori mogući su i održavaju se u svim državama bivše Jugoslavije, sa izuzetkom Bosne i Hercegovine.

Mogućnost održavanja vanrednih izbora nije zapriječena Ustavom $\mathrm{BiH}$. Naprotiv, osim u slučaju članova Predsjedništva BiH, u kom slučaju je eksplicitno propisano da njihov mandat traje četiri godine, ${ }^{29}$ Ustav $\mathrm{BiH}$ ne precizira trajanje mandata poslanika ili delegata u Parlamentarnoj skupštini BiH. Naprotiv, Ustav BiH jasno propisuje da će poslanici u Predstavničkom domu biti birani „u skladu sa izbornim zakonom kojeg će donijeti Parlamentarna skupština“"30, čime je zakonodavcu ostavljena puna diskrecija po pitanju trajanja njihovog mandata, uključujući mogućnost skraćivanja takvog mandata u slučaju ukazane potrebe za održavanje vanrednih izbora. Izborni zakon $\mathrm{BiH}$, međutim, nije propisao mogućnost raspuštanja Predstavničkog doma Parlamentarne skupštine BiH, niti prijevremenih izbora za taj nivo vlasti.

Istovremeno, Ustav $\mathrm{BiH}$ eksplicitno propisuje mogućnost raspuštanja Doma naroda - čiji članovi nisu izabrani, već su delegirani od strane entitetskih parlamenata - bilo odlukom Predsjedništva BiH ili samog Doma naroda. ${ }^{31}$ Uzimajući, međutim, u obzir da Dom naroda ne učestvuje u izboru

\footnotetext{
${ }^{27}$ Za potrebe ovog teksta, pod vanrednim izborima mogu se smatrati izbori koji se održavaju izvan eksplicitno preciziranih termina, uključujući značajno prije krajnjeg roka za njihovo održavanje.

${ }^{28}$ Sistem u kom su članovi izvršne vlasti (vlade) istovremeno i poslanici u zakonodavnom tijelu (parlamentu).

${ }^{29}$ Član V.2.b) Ustava BiH.

${ }^{30}$ Član IV.2.a) Ustava BiH.

${ }^{31}$ Član IV.3.g) Ustava BiH.
} 
Vijeća ministara $\mathrm{BiH}$, ova odredba nije dostatna za potrebe saniranja posljedica kada ne postoji parlamentarna većina za imenovanje Vijeća ministara $\mathrm{BiH}$, odnosno kada Vijeće ministara BiH izgubi podršku većine u ovom domu.

Iako prvih nekoliko izbornih ciklusa nakon usvajanja Izbornog zakona BiH nije ukazivalo na potrebu uvođenja mogućnosti vanrednih izbora na nivou Parlamentarne skupštine $\mathrm{BiH}$, ta potreba se pojavila već nakon Općih izbora 2010. godine, kada je Bosna i Hercegovina čekala više od šesnaest mjeseci na formiranje nove vlasti. Slična situacija se pojavila nakon izbora 2018. godine, kada je proces formiranja vlasti na državnom nivou trajao gotovo petnaest mjeseci, a isti još uvijek nije okončan na nivou Federacije BiH, gdje nova Vlada tog entiteta nije izabrana ni više od dvije godine nakon izbora. Također, rezultati izbora još uvijek nisu implementirani u Hercegovačkoneretvanskom kantonu.

Kada su entiteti u pitanju, Ustav Federacije BiH eksplicitno propisuje da i Predstavnički i Dom naroda mogu - jedan ili oba istovremeno - biti raspušteni kada predsjednik Federacije, uz saglasnost potpredsjednika, utvrdi da "domovi nisu u mogućnosti donijeti potrebne zakone," $32 \mathrm{~s}$ tim da niti jedan dom ne može biti raspušten "u periodu od godinu dana od njegovog prvog sazivanja". ${ }^{33}$ Šta više, iako prethodna odredba predstavlja diskreciono pravo predsjednika i potpredsjednika Federacije $\mathrm{BiH}$, predsjednik Federacije $\mathrm{BiH}$ je obavezan raspustiti oba doma "kad oni ne uspiju donijeti budžet Federacije prije početka budžetske godine." 34

Slična situacija postoji i u entitetu Republika Srpska, čiji ustav dozvoljava raspuštanje Narodne skupštine, kao i skraćivanje mandata iste, u kom slučaju prestaje i mandat Vijeća naroda. ${ }^{35}$ Obje situacije su tretirane Izbornim zakonom BiH, koji propisuje postupanje za potrebe prijevremenih izbora za Parlament Federacije BiH, odnosno Narodnu skupštinu RS.

Iako postoji mogućnost da vanredni izbori pojačaju političku nestabilnost, oni istovremeno potiču kompromis, pogotovo u situacijama u kojima dolazi do automatskog raspuštanja parlamenta i sazivanja novih izbora ukoliko se vlada ne izabere, ili pak budžet ne usvoji, do preciziranog datuma. ${ }^{36}$ Suočeni sa neizvjesnošću rezultata novih izbora, pogotovo nakon nemogućnosti sastavljanja vlade ili budžetskog djelovanja, političke stranke su u pravilu spremnije na kompromisno djelovanje nego u slučajevima u kojim dalje odlaganje

\footnotetext{
${ }^{32}$ Ustav Federacije BiH, Poglavlje IV.A.

${ }^{33}$ Ibid.

${ }^{34}$ Ibid.

${ }^{35}$ Ustav Republike Srpske, član 72. i Amandman LXXIX.

${ }^{36}$ Primjera radi, tri ili šest mjeseci nakon izbora.
} 
ne nosi bilo kakve trenutne političke posljedice. Šta više, sami izabrani članovi tih stranaka imaju motiv da vrše pritisak na stranačku rukovodstvo da kompromis postignu, kako bi izbjegli mogućnost gubitka mandata na prijevremenim izborima.

Identična argumentacija aplicira i po pitanju finansijskih troškova koje održavanje vanrednih ili prijevremenih izbora iziskuje. Naime, mogućnost održavanja takvih izbora ne znači nužno da će do njih i doći. Istovremeno, te kako je iznad navedeno, ta mogućnost potiče spremnost na kompromis, što rezultira manjim posljedicama po ekonomiju nego prolonigarano djelovanje vlada u tehničkim mandatima.

$\mathrm{S}$ obzirom na navedene primjere, mogućnost prijevremenih izbora bi u Bosni i Hercegovini bi bilo korisno propisati ne samo na državnom nivou, već i na entitetskim i kantonalnim nivoima. Uzimajući u obzir da je formiranje vlasti na jednom nivou često uslovljeno postizanjem kompromisa između istih stranaka na drugom nivou, mogućnost prijevremenih izbora na ${ }^{37}$ različitim nivoima bi služila kao dodatni poticaj za te stranke da postignu sveobuhvatni kompromis.

\section{Povećanje izbornog cenzusa}

Usko vezano za pitanje prijevremenih ili vanrednih izbora je i pitanje izbornog cenzusa. Naime, relativno česta nemogućnost formiranja vlasti ili pak nestabilnih parlamentarnih većina je i činjenica da Bosna i Hercegovina ima daleko najniži izborni cenzus u regiji, te među najnižim u svijetu. Konkretno, samo 3\% glasova je neophodno da bi politička stranka prešla prag za osvajanje mandata $u$ datom zakonodavnom tijelu, što u pravilu rezultira stalnom proliferacijom političkih stranaka i nezavisnih kandidata, te pratećim velikim brojem političkih subjekata u zakonodavnim tijelima širom Bosne i Hercegovine.

Primjera radi, u Predstavničkom domu Parlamentarne skupštine $\mathrm{BiH}$, koji broji samo 42 poslanika, zastupljeno je čak 15 političkih subjekata. ${ }^{38} \mathrm{U}$ Parlamentu Federacije BiH djeluje 16 političkih subjekata ${ }^{39}$, dok u Skupštini Kantona Sarajevo - koja obuhvata poslanike samo jednog od deset kantona u Federaciji $\mathrm{BiH}$ - djeluje njih devet. ${ }^{40}$

\footnotetext{
${ }^{37}$ Član 9.5(3) Izbornog zakona BiH

${ }^{38} \mathrm{http} / / /$ parlament.ba/representative/list

${ }^{39} \mathrm{https}: / /$ predstavnickidom-pfbih.gov.ba/bs/page.php?id=5

${ }^{40} \mathrm{https}$ ://skupstina.ks.gov.ba/sastav/zastupnici/po-strankama/all
} 
Iako Parlamentarna skupština Vijeća Evrope preporučuje da se izborni cenzus ne kreće iznad 3\% „u dobro utvrđenim demokratijama“, ${ }^{41}$ većina evropskih zemalja je taj cenzus postavila na 5\%. Šta više, Evropski sud za ljudska prava je odlučio da izborni cenzus od čak $10 \%$ koji se primjenjuje u Turskoj ne predstavlja kršenje Evropske konvencije o ljudskim pravima, iako su konkretni izbori zbog kojih je sud pitanje i razmatrao rezultirali neimplementacijom izborne volje čak $45 \%$ glasača. ${ }^{42}$

Praksa među državama bivše Jugoslavije je neujednačena. Naime, dok Hrvatska i Slovenija održavaju izborni cenzus na $5 \%$, odnosno $4 \%$, on je u Crnoj Gori 3\%, što predstavlja isti procenat koji je Srbija uvela prije izbora 2020. godine. ${ }^{43}$ Kako je iznad i navedeno, međutim, cilj prijedloga navedenih u ovom tekstu nije da izjednači izbornu praksu Bosne i Hercegovine sa državama regije ili pak Evrope, već da ukaže na rješenja koja su se u praksi pokazala lošim u konkretnom slučaju Bosne i Hercegovine.

S tim u vezi, izborni prag je 2020. godine u Srbiji spušten na 3\% jer su sve relevantne ankete ukazivale da gotovo nijedna opoziciona stranka neće moći preći prijašnji prag od 5\%, a vladajuća Srpska napredna stranka - već suočena sa optužbama za režimsko djelovanje - je pokušala održati barem primjesu postojanja opozicije u Srbiji, upravo kako bi odbacila takve optužbe. ${ }^{44}$ I pored ovog političkog manevra, samo su tri stranke prešle izborni prag od 3\% u skupštini koja broji 250 poslanika. ${ }^{45}$

Kako je već navedeno, praksa u Bosni i Hercegovini je potpuno obrnuta, te nizak izborni prag dovodi do preglomaznog broja političkih subjekata u gotovo svim skupštinskim klupama. Ovo dovodi do neproporcionalnog uticaja manjih stranaka, ili čak nezavisnih kandidata, koji insistiraju na lukrativnim pozicijama u vlasti u zamjenu za svoju podršku datoj parlamentarnoj većini. ${ }^{46}$ U takvim situacijama te pozicije se u pravilu ne koriste za promociju politike vladajuće većine, već primarno za promociju uskih interesa stranke koja istim upravlja.

\footnotetext{
${ }^{41}$ Parlamentarna skupština Vijeća Evrope, Rezolucija 1547 (2007), http://assembly.coe.int/nw/xml/ XRef/Xref-XML2HTML-en.asp?fileid=17531\&lang=en

${ }^{42}$ Evropski sud za ljudska prava, Yumak-Sadak v. Turkey (2008). Konkretno, 45\% glasača je glasalo za stranke koje nisu prešle navedeni izborni prag od $10 \%$. Ibid.

${ }^{43}$ Vidjeti https://www.danas.rs/politika/smanjen-cenzus-na-tri-odsto-na-listama-najmanje-40-odsto-zena/.

${ }^{44}$ Ibid.

${ }^{45}$ Mandate su također osvojili predstavnici četiri nacionalne manjine, za koje se primjenjuju zasebna pravila.

${ }_{46}$ Vidjeti https://radiosarajevo.ba/metromahala/teme/esed-radeljas-predsjednik-uo-zavoda-zdravstvenog-osiguranja-ks/128023
} 
Iz navedenih razloga je jasno da povećanje izbornog cenzusa odgovara velikim strankama koje su u pravilu i činile vlast tokom proteklog desetljeća, jer u tom slučaju ne bi bile prisiljene da prepuštaju značajan i neproporcionalan broj pozicija manjim strankama. Primarni razlog zbog kog cenzus nije povećan, međutim, leži u činjenici da bi u takvom slučaju povratnička populacija u entitetu Republika Srpska gotovo sigurno bila uskraćena za određeni broj mjesta u Narodnoj skupštini Republike Srpske, kao i za bilo kakvu zastupljenost u Parlamentarnoj skupštini BiH.

Naime, od stranaka sa sjedištem u Federaciji BiH koje djeluju u Republici Srpskoj, samo je jedna prešla izborni cenzus od tri posto na prošlim općim izborima (no osvojivši manje od pet posto) za izbore u Parlamentarnu skupštinu $\mathrm{BiH}$ iz tog entiteta, ${ }^{47}$ dok sve ostale zajedno nisu ostvarile taj procenat glasova. Za potrebe izbora u Narodnu skupštinu RS na istim općim izborima, čitava koalicija stranaka koje djeluju u Federaciji BiH ostvarila je samo $4,32 \%$ glasova. ${ }^{48}$ Gotovo identična situacija je viđena i na Općim izborima 2014. godine ${ }^{49}$ a također je prisutna na lokalnim izborima u većini općina $u$ kojima živi povratnička populacija. ${ }^{50}$ Bilo kakvo povećanja izbornog cenzusa bi, stoga rezultiralo praktičnim nestankom tih stranaka iz političkog života u RS entitetu.

U Bosni i Hercegovini, naravno, nije moguće primjeniti zasebne liste za „nacionalne manjine“, po uzoru na Srbiju ili Hrvatsku, uzimajući u obzir da su pripadnici povratničkih populacija konstitutivni narodi u Bosni i Hercegovini, a ne nacionalne manjine. Nije, također, moguće propisati niži prag za stranke koje su registrovane u drugom entitetu jer bi to ne samo bilo politički neprihvatljivo, već bi neminovno dovelo do zloupotreba, a gotovo sigurno ne bi bilo u skladu sa načelima zabrane diskriminacije iz Ustava $\mathrm{BiH}$ i Evropske konvencije o ljudskim pravima.

Istovremeno, povećanje izbornog cenzusa na 5\% bi motivisalo stranke sa sličnim programskim ciljevima na datom području (promocija interesa povratničke populacije) da koaliraju sa zajedničkim listama. Iznad navedeni primjeri ukazuju da bi te stranke, uz disciplinovano koaliranje, bile u stanju

\footnotetext{
${ }^{47}$ Centralna izborna komisija BiH (CIK BiH), Rezultati izbora, Opći izbori 2018, http://www.izbori.ba/ rezultati_izbora?resId $=25 \&$ langId $=1 \# / 1 / 0 / 0 / 0 / 0$

${ }^{48}$ Ibid.

${ }^{49} \mathrm{CIK}$ BiH, Rezultati izbora, Opći izbori 2014., http://www.izbori.ba/Default.aspx?CategoryID=541 \&Lang $=3$

${ }^{50} \mathrm{CIK}$ BiH, Rezultati izbora, Lokalni izbori 2016., http://www.izbori.ba/Default.aspx?CategoryID=700 \&Lang $=3$
} 
preći prag od 5\%, a što bi također doprinijelo njihovoj relativnoj snazi po pitanju promocije navedenih interesa.

Uzimajući u obzir sve navedeno, evidentno je da bi povećanje izbornog cenzusa sa tri na pet posto bilo korisno po političku stabilnost Bosne i Hercegovine, a da bi primarni razlog za izbjegavanje usvajanja takvog rješenja - interesi povratničke populacije - mogao biti adresiran kroz čvršće predizborne koalicije onih stranaka koje se zalažu za interese te populacije, koje koalicije bi bile zasnovane na jasnim programima.

\section{Drugi krug izbora}

Za razliku od svih susjednih zemalja i većine evropskih država, Izborni zakon $\mathrm{BiH}$ ne predviđa drugi krug izbora za direktno izabrane izvršne pozicije, poput članova Predsjedništva $\mathrm{BiH}$, predsjednika i potpredsjednika Republike Srpske, te gradonačelnika i općinskih načelnika. Naprotiv, Izborni zakon BiH precizira da je na svaku od ovih pozicija izabran onaj kandidat koji osvoji najveći broj glasova. ${ }^{51}$

U gotovo svim situacijama u kojim na izborima za datu poziciju učestvuje više od dva kandidata - što nisu rijetke situacije uzimajući u obzir iznad istaknutu proliferaciju političkih subjekata u Bosni i Hercegovini - na navedene pozicije budu izabrani kandidati koji ne uživaju većinsku podršku glasača.

Primjera radi, u trenutnom sazivu Predsjedništva $\mathrm{BiH}$, jedan član je izabran sa samo $36 \%$ glasova. ${ }^{52} \mathrm{U}$ prethodna dva saziva (izbori 2014. i 2010.), ${ }^{53} \mathrm{kao}$ i na izborima 2002. godine ${ }^{54}$, dva člana Predsjedništva su izabrana sa manje od $50 \%$ glasova. Kako je i na izborima 2006. ${ }^{55}$ jedan član Predsjedništva BiH izabran sa manje od 50\% glasova, zadnji put kada su sva tri člana Predsjedništva $\mathrm{BiH}$ izabrana većinom glasova su održani prije 22 godine (1998.). ${ }^{56}$

Kada su u pitanju načelnici/gradonačelnici, na Lokalnim izborima 2020. godine, gotovo $25 \%(24,68 \%)$ ih je izabrano glasovima manje od $50 \%$ glasača

\footnotetext{
${ }^{51}$ Izborni zakon BiH, čl. 8.1(2)., čl. 12.3 i čl 13.7. Izbor gradonačelnika i načelnika dodatno je propisan i kroz Zakon o izboru prestanku mandata, opozivu i zamjeni načelnika u Federaciji Bosne i Hercegovine, te Izborni zakon Republike Srpske.

${ }^{52}$ CIK BiH, Rezultati izbora, Opći izbori 2018, http://www.izbori.ba/Default.aspx?CategoryID=916 \&Lang=3

${ }^{53} \mathrm{CIK}$ BiH, Rezultati izbora, Opći izbori 2010, http://www.izbori.ba/Default.aspx?CategoryID=258 \&Lang=3 i Opći izbori 2014., http://www.izbori.ba/Default.aspx?CategoryID=541\&Lang=3

${ }^{54} \mathrm{CIK}$ BiH, Rezultati izbora, Opći izbori 2002, http://www.izbori.ba/Default.aspx?CategoryID=227 \&Lang $=3$

${ }^{55} \mathrm{CIK}$ BiH, Rezultati izbora, Opći izbori 2006, http://www.izbori.ba/Default.aspx?CategoryID=230 \&Lang $=3$

${ }^{56} \mathrm{CIK}$ BiH, Rezultati izbora, Opći izbori 1998, http://www.izbori.ba/Default.aspx?CategoryID=223 \&Lang $=3$
} 
u njihovim općinama širom Bosne i Hercegovine, ${ }^{57}$ procenat koji je gotovo identičan tokom prethodna dva izborna ciklusa na lokalnim izborima. ${ }^{58}$

Ovakav način izbora članova Predsjedništva i načelnika/gradonačelnika dovodi do kontinuiranih i brojnih situacija u kojim se kandidati biraju na ove funkcije iako $60 \%$, pa i više, glasača glasa za druge kandidate. Također, kandidati osvajaju bitne izvršne funkcije sa relativno malom razlikom glasova, čime se frustrira izborna volja značajnog broja birača.

Primjera radi, na Općim izborima 2018. godine, za člana Predsjedništva $\mathrm{BiH}$ iz reda bošnjačkog naroda izabran je kandidat koji je osvojio 36,61\% glasova, dok je idući rangirani kandidat dobio $35,53 \%$ glasova.$^{59}$ Od blizu 600.000 važećih glasova, razlika između dva kandidata bila je manja od 18.000, što je istovremeno i četiri puta manje od ukupnog broja nevažećih listića. ${ }^{60}$ Slična situacija javila se na Općim izborima 2014. godine po pitanju izbora člana Predsjedništva $\mathrm{BiH}$ iz reda srpskog naroda. Tada je razlika između dva kandidata iznosila 1\%, odnosno samo 6.000 glasova od ukupno 650.000 važećih. ${ }^{61}$

Da ove situacije nisu rijetke kada je u pitanju izbor članova Predsjedništva $\mathrm{BiH}$ pokazuje i gotovo identična situacija izbora člana Predsjedništva $\mathrm{BiH}$ iz reda srpskog naroda na Općim izborima 2010. godine, kada je dva kandidata dijelilo nešto više od 1\%, odnosno 9.000 glasova od preko 600.000 važećih. ${ }^{62}$ Također, na Općim izborima 2002. godine razlika između dva najbolje rangirana kandidata za člana Predsjedništva $\mathrm{BiH}$ iz reda bošnačkog naroda iznosila je samo 3\%, odnosno 15.000 glasova od preko 515.000 važećih. ${ }^{63}$

U konačnici, osim izbora 1996. i 1998. godine, niti jedan saziv Predsjedništva $\mathrm{BiH}$ nije imao sva tri člana sa punim izbornim legitimitetom, odnosno sa većinom osvojenih glasova. Konkretno, na izborima 2002. godine, članovi iz reda bošnjačkog i srpskog naroda izabrani su sa manje od 50\% glasova, što je bio i slučaj sa članom Predsjedništva BiH iz reda hrvatskog

\footnotetext{
${ }^{57} \mathrm{CIK}$ BiH, Rezultati izbora, Lokalni izbori 2020, https://www.izbori.ba/Rezultati_izbora/?resId=27\& langId $=1 \# / 8 / 0 / 0$

${ }^{58} \mathrm{CIK}$ BiH, Rezultati izbora, Lokalni izbori 2016, http://www.izbori.ba/Default.aspx?CategoryID=700 \&Lang=3 i Lokalni izbori 2012., https://www.izbori.ba/Default.aspx?CategoryID=382\&Lang=3

${ }^{59} \mathrm{CIK}$ BiH, Rezultati izbora, Opći izbori 2018, http://www.izbori.ba/Default.aspx?CategoryID=916 \&Lang $=3$

${ }^{60}$ Ibid.

${ }^{61} \mathrm{CIK}$ BiH, Rezultati izbora, Opći izbori 2014, http://www.izbori.ba/Default.aspx?CategoryID=541 \&Lang $=3$

${ }^{62} \mathrm{CIK}$ BiH, Rezultati izbora, Opći izbori 2010, http://www.izbori.ba/Default.aspx?CategoryID=258 \&Lang $=3$

${ }^{63} \mathrm{CIK}$ BiH, Rezultati izbora, Opći izbori 2002, http://www.izbori.ba/Default.aspx?CategoryID=227 $\&$ Lang $=3$
} 
naroda 2006. godine. Na izborima 2010. i 2014. godine ponovila se situacija u kojoj niti bošnjački niti srpski član Predsjedništva nisu osvojili većinu glasova, a bošnjački član to nije uspio ni na izborima 2018. godine. ${ }^{64} \mathrm{~S}$ tim u vezi, od Daytona do danas čak četiri člana Predsjedništva $\mathrm{BiH}$ iz reda bošnjačkog naroda su izabrani sa manje od 50\% glasova, što je bio slučaj i sa tri člana Predsjedništva $\mathrm{BiH}$ iz reda srpskog naroda, te sa jednim članom iz reda hrvatskog naroda. ${ }^{65}$

Postojanje drugog kruga glasanja bi u ovim i sličnim situacijama bilo nadasve poželjno, jer bi omogućilo glasačima da jasno iskažu svoju volju, a istovremeno bi ojačalo izborni legitimitet onih kandidata koji bi u konačnici bili izabrani većinom glasova.

Nedostaci drugog kruga glasanja se primarno odnose na troškove, te na produženje neizvjesnosti, što uključuje zastoj u promociji interesa građana do okončanja izbornog procesa. Činjenica je da izbori predstavljaju značajan izdatak za budžet Bosne i Hercegovine, te da u prosjeku koštaju između 10 i 12 miliona KM po izbornom ciklusu. Svaki dodatni krug glasanja bi dodatno povisio te troškove.

U demokratskim zemljama, međutim, česta je praksa preferencijalnog glasanja, koje se još naziva i instant-drugi-krug glasanja. Primjera radi, taj sistem se primjenjuje na izborima za predsjednika Irske i Indije, na parlamentarnim izborima u Australiji, kako saveznim tako i unutar samih saveznih država, izborima za poslanike u američkoj saveznoj državi Maine i slično.

Prema ovom sistemu, glasači rangiraju kandidate, počev sa brojem 1 za prvu preferensu i tako dalje. Ukoliko niti jedan kandidat ne dobije preko 50\% prvih preferensi, dva kandidata sa najvećim brojem tih preferensi ulaze u tzv. instant drugi krug, tako što im se dodijeljuju njihove preferense broj 2 sa listića onih kandidata koji nisu ušli u instant drugi krug. Kada se iscrpe sve preferense broj 2, obojici se dodijeljuju njihove preferense broj 3 sa preostalih listića, i tako redom. Kandidat koji na kraju ima više glasova je izabran.

Ovaj sistem glasanja i izbora omogućava izbor kandidata koji ima najveću i najširu podršku. Istovremeno, ovaj izbor ne stvara dodatne troškove niti neizvjesnost jer preferencijalni sistem glasanja predstavlja instant drugi krug. Iskustvo zemalja koje primjenjuju ovaj sistem ukazuje da vrijeme za brojanje ne varira u odnosu na obično brojanje, a to je pogotovo slučaj u Bosni i Hercegovini gdje bi se ovi listići svakako izbrojali znatno prije listića za zakonodavne organe, čije brojanje iziskuje dosta vremena.

\footnotetext{
${ }^{64}$ Vidjeti CIK BiH rezultate izbora za konkretne izborne cikluse, kako je navedeno iznad. ${ }^{65}$ Ibid.
} 
Ovo rješenje je moguće usvojiti bez izmjena Ustava BiH. Naime, Ustav Bosne i Hercegovine propisuje: „Članovi Predsjedništva biraju se neposredno u svakom entitetu (tako da svaki glasač glasa za popunjavanje jednog mjesta u Predsjedništvu), u skladu sa izbornim zakonom kojeg donosi Parlamentarna skupština." ${ }_{66}$

Parlamentarna skupština $\mathrm{BiH}$, stoga, može mijenjati način izbora članova Predsjedništva $\mathrm{BiH}$ pod uslovom da je izbor 1. neposredan, 2. da se odvija zasebno u svakom entitetu, te 3 . da svaki glasač može glasati za popunjavanje samo jednog od tri mjesta u Predsjedništvu BiH. Ovi uslovi bi nesumnjivo bili zadovoljeni po pitanju uspostave instant drugog kruga glasanja za članove Predsjedništva $\mathrm{BiH}$, te bi ovu promjenu bilo jednostavno implementirati i time Bosnu i Hercegovinu približiti evropskoj demokratskoj praksi, bez gotovo bilo kakvih dodatnih troškova.

Kada je u pitanju način izbora načelnika/gradonačelnika, isti ne podliježe bilo kakvim ustavnim restrikcijama. Entitetski zakoni, međutim, propisuju da je u izborima za načelnike/gradonačelnike izabran onaj kandidat koji ima najviše glasova, te je ove zakone - Zakon o izboru prestanku mandata, opozivu i zamjeni načelnika u Federaciji Bosne i Hercegovine, te Izborni zakon Republike Srpske - također neophodno izmjeniti u relevantnim dijelovima kako bi ovaj prijedlog bilo moguće sprovesti i po pitanju čelnih zvaničnika gradova i općina u Bosni i Hercegovini.

\section{Moderne tehnologije u izbornom procesu}

Bosna i Hercegovina ne koristi bilo kakve moderne tehnologije u izbornom procesu, kako po pitanju elektronskog glasanja ili elektronskog brojanja glasova. Naprotiv, sistem glasanja i brojanja glasova nije promijenjen ne samo od stupanja na snagu Izbornog zakona $\mathrm{BiH}$, prije 20 godina, već je u suštinskom smislu identičan onom koji je primjenjen na prvim višestranačkim izborima prije tačno 30 godina. ${ }^{67}$

Pitanje elektronskog glasanja je, međutim, postalo toliko prisutno u modernim demokratijama da je Vijeće Evrope 2017. godine usvojilo Preporuke o standardima elektronskog glasanja za potrebe 47 članica ove međunarodne organizacije, među kojima je i Bosna i Hercegovina. ${ }^{68}$ Te Preporuke prihvataju elektronsko glasanje, kao i elektronsko brojanje, kao normalnu činjenicu

\footnotetext{
${ }^{66}$ Ustav BiH, čl. V.1.

${ }^{67}$ Kao i tada, glasači još uvijek glasaju markiranjem kandidata olovkom na papirnim listićima, koje ubacuju u glasačke kutije. Listiće po zatvaranju izbornih mjesta prebrojavaju članovi biračkih odbora.

${ }^{68} \mathrm{Vidjeti}$ https://search.coe.int/cm/Pages/result_details.aspx?ObjectId=0900001680726f6f
} 
u modernim demokratskim društvima, te državama isključivo ukazuju na potrebu osiguravanja određenih standarda prilikom primjene tih modernih tehnologija. Konkretno, Preporuke drže da je kod uvođenja elektronskog glasanja i brojanja neophodno osigurati univerzalno, jednako, slobodno i tajno glasanje, postepenu prilagodbu, transparentnost i posmatranje izbora, te sigurnost sistema. ${ }^{69}$

Uvođenje elektronskog glasanja kao takvog nikada se nije našlo u formi zvaničnog prijedloga u Bosni i Hercegovini, a razlozi se kreću od finansijskih, preko logističkih, do sigurnosnih. Istovremeno, Bosna i Hercegovina je tokom prošlog mandata Parlamentarne skupštine $\mathrm{BiH}$ bila izuzetno blizu uvođenju elektronskog brojanja glasova, ali je taj prijedlog osujećen u Domu naroda nakon što je prethodno usvojen u Predstavničkom domu.

Kada je u pitanju elektronsko glasanje, činjenica je da bi uspostava takvog sistema zahtijevala značajna finansijska sredstva. Naime, uzimajući u obzir da se glasanje u Bosni i Hercegovini obavlja na oko 5.500 biračkih mjesta, ${ }^{70}$ te da je u prosjeku omogućeno istovremeno glasanje tri osobe na jednom biračkom mjestu, bilo bi neophodno nabaviti minimalno 15.000 mašina za elektronsko glasanje kako bi se ispoštovale iznad navedene Preporuke Vijeća Evrope. Troškovi nabavke tih uređaja bi predstavljali samo dio ukupnih troškova, koji bi svakako bili uvećani zbog potreba njihovog održavanja, ažuriranja softwara, te drugih pratećih dugoročnih troškova.

Garantovanje sigurnosti ovog sistema bi zahtijevalo dodatne troškove, kao što je i slučaj sa obukom osoblja i upoznavanjem glasača sa svim njegovim karakteristikama. S tim u vezi, te također u skladu sa Preporukama Vijeća Evrope, sistem ne bi bilo moguće uvesti na prvim idućim izborima, već bi bilo neophodno organizovati postepenu primjenu, kroz pilot projekte i drugu vrstu testiranja.

S obzirom na sve navedeno, u Bosni i Hercegovini je zvanično razmatrano isključivo elektronsko brojanje glasova, a što se smatralo prihvatljivom kombinacijom zadovoljavanja potrebe jačanja integriteta izbornog procesa $\mathrm{s}$ jedne strane, te minimiziranja troškova i zadovoljavanja svih preporuka Vijeća Evrope s druge strane.

Naime, ukoliko bi se optički skeneri uveli na svakom biračkom mjestu, bilo bi potrebno tri puta manje istih u odnosu na elektronske uređaje za glasanje, što bi predstavljalo značajne uštede. Šta više, značajno bi bila smanjena

\footnotetext{
${ }^{69}$ Ibid.

${ }^{70} \mathrm{CIK}$ BiH, Rezultati izbora, Opći izbori 2018, http://www.izbori.ba/Default.aspx?CategoryID=916 \&Lang $=3$.
} 
potreba upoznavanja glasača sa novim tehnologijama jer bi bio zadržan postupak popunjavanja papirnih glasačkih listića olovkama, te bi se obuka isključivo odnosila na osoblje na biračkim mjestima koje bi te listiće obrađivalo kroz optičke skenere.

Po pitanju integriteta izbornog procesa, članovi CIK BiH i drugi stručnjaci na ovom polju su saglasni da su birački odbori - koji su trenutno odgovorni za brojanje glasova - „najslabija karika“ tog procesa. ${ }^{71}$ Istovremeno, troškovi koji se tokom svakog izbornog ciklusa izdvajaju za naknade članova biračkih odbora iznose oko 4,5 miliona KM, što predstavlja između 40 i 50\% ukupnih troškova organizacije izbora. ${ }^{72}$ Uzimajući u obzir da za potrebe identifikacije birača i obrađivanja glasačkih listića ne bi bilo potrebno pet članova koliko ih je trenutno angažovano na prosječnom biračkom mjestu, ${ }^{73}$ dio ovih troškova bi bio smanjen kroz uvođenje elektronskog brojanja glasova.

Centralna izborna komisija je, prvenstveno zbog ovih činjenica, poduzela određene radnje s ciljem promocije naprednih tehnologija u izbornom procesu $^{74}$, a potom je u februaru 2016. godine organizovala i prezentaciju takvih različitih naprednih tehnologija u prostorijama Parlamentane skupštine $\mathrm{BiH}$, te je naknadno izdala i publikaciju o novim tehnologijama u izbornom procesu. $^{75}$

S obzirom na sve navedeno, grupa poslanika u Parlamentarnoj skupštini $\mathrm{BiH}$ je u februaru 2018. godine u proceduru uputila prijedlog izmjena Izbornog zakona $\mathrm{BiH}$, kojim je predložila uvođenje elektronskog brojanja glasova.$^{76}$ Konkretno, kada je u pitanju ključni dio ovog zakonskog rješenja, prijedlog je predviđao evidentiranje rezultata izbora na osnovu izvoda iz optičkih skenera, ${ }^{77}$ odnosno elektronsko brojanje glasova. Prijedlog zakona je precizirao da $\mathrm{CIK} \mathrm{BiH}$ propisuje procedure koje pored elektronskog brojanja

\footnotetext{
${ }^{71}$ Vidjeti, inter alia, Irena Hadžiabdić: Birački odbori su najslabija karika, Nezavisne novine, 9. 5. 2010, https://www.nezavisne.com/novosti/intervju/Irena-Hadziabdic-Biracki-odbori-su-najslabija-karika/59575 i Neautorizirani transkript stručnog savjetovanja o izbornom zakonodavstvu „Status izbornog zakonodavstva u BiH: Izborna administracija, kandidatske liste i mandati”, u organizaciji ustavnopravnih komisija oba doma Parlamentarne skupštine $\mathrm{BiH}, 18$. 9. 2013, izlaganje predsjednika CIK BiH Stjepana Mikića, str. 14-15, www.parlament.ba .

${ }^{72}$ Vidjeti https://www.klix.ba/vijesti/bih/clanovi-birackih-odbora-cesto-odustaju-jer-su-nedovoljno-placeni-a-onda-uskacu-iskusni-igraci/180927141.

${ }^{73}$ Izborni zakon BiH, čl. 2.19.

${ }^{74}$ Akt CIK BiH br. 04-50-2-32-8/16 od 26. 1. 2016. godine.

${ }^{75}$ Vidjeti http://www.izbori.ba/Documents/2017/N_T_2017/Nove_tehnologije.pdf.

${ }^{76}$ Prijedlog zakona o izmjenama i dopunama Izbornog zakona BiH , br. 01-02-1-629/18 od 28.02.2018. godine, predlagači: poslanici u Predstavničkom domu Parlamentarne skupštine BiH Mirsad Mešić, Damir Arnaut, Denis Bećirović, Saša Magazinović, Damir Bećirović, Fehim Škaljić i Mirsad Đonlagić. ${ }^{77}$ Ibid., čl. 4.
} 
omogućavaju i ručno brojanje na jednom ili više biračkih mjesta, uz uslov da ukoliko dođe do razlike u rezultatima između ručnog i elektronskog brojanja, ponovno optičko skeniranje i brojanje se obavlja od strane CIK BiH u Glavnom centru za brojanje. ${ }^{78}$

Prijedlog zakona je također predviđao identifikaciju birača putem skeniranja otiska prsta, ${ }^{79}$ a uzimajući u obzir brojne manipulacije sa ličnim kartama odsutnih glasača, te nadgledanje svih biračkih mjesta putem video nadzora. ${ }^{80}$ Prijedlog zakona je također predviđao uspostavu mehanizama kojim bi se olakšalo glasanje slijepih, nepismenih ili osoba koje su fizički nesposobne da samostalno glasaju, ${ }^{81}$ te su značajno pooštrene sankcije za manipulacije tokom izbornog procesa. ${ }^{82}$

Ovaj prijedlog zakona je usvojen u Predstavničkom domu po hitnom postupku na prvoj narednoj sjednici nakon što je isti upućen u proceduru. ${ }^{83} \mathrm{Od}$ 38 prisutnih poslanika, za prijedlog zakona glasalo je čak 28 poslanika iz 10 različitih stranaka, 9 je bilo protiv (svi iz SNSD i HDZ) i 1 suzdržan. ${ }^{84}$ S obzirom da je na istoj sjednici usvojen zaključak kojim je Predstavnički dom od Doma naroda tražio da zakon također razmatra po hitnom postupku, ${ }^{85}$ ovaj prijedlog zakona razmatran je na narednoj sjednici Doma naroda, već u drugoj polovini marta iste godine, odnosno dvije sedmice nakon usvajanja $u$ Predstavničkom domu. ${ }^{86}$

Nakon odgađanja izjašnjavanja na toj sjednici, međutim, zahtjev za hitni postupak odbijen je u maju iste godine, ${ }^{87}$ a zakon je potom odbijen i u redovnom postupku prihvatanjem negativnog mišljenja nadležne Ustavnopravne komisije. ${ }^{88}$ Uzimajući u obzir da je osam delegata u Domu naroda, od ukupno 15 , glasalo protiv hitne procedure, ${ }^{89}$ samo jedan glas dijelio je Bosnu i

\footnotetext{
${ }^{78}$ Ibid.

${ }^{79}$ Ibid., čl. 5. i 6.

${ }^{80}$ Ibid., čl. 7.

${ }^{81}$ Ibid., čl. 17.

${ }^{82}$ Ibid., čl. 27.

${ }^{83}$ 58. sjednica Predstavničkog doma, 7. 3. 2018. godine, http://www.parlament.ba/olaw/OLawDetails? lawId $=60646$

${ }^{84}$ Ibid., Listing glasanja o Prijedlogu zakona

${ }^{85}$ Ibid., Listing glasanja o Prijedlogu zaključka grupe poslanika

${ }^{86}$ 37. sjednica Doma naroda, 21. 3. 2018. godine, http://www.parlament.ba/olaw/OLawDetails?lawId $=60646$

${ }^{87}$ 39. sjednica Doma naroda, 15. 5. 2018. godine, http://www.parlament.ba/olaw/OLawDetails?lawId $=60646$

${ }^{88}$ Procedura u Domu naroda, http://www.parlament.ba/olaw/OLawDetails?lawId=60646

${ }^{89}$ Ibid.
} 
Hercegovinu od uspostave elektronskog brojanja, koji sistem bi se primijenio već na Općim izborima koji su održani u oktobru te godine.

Uzimajući u obzir da su na tim, ali i na Lokalnim izborima 2020. godine, evidentirane brojne manipulacije i malverzacije, ${ }^{90}$ te da niti tri godine nakon neuspjeha ove zakonodavne inicijative nije ponuđeno novo zakonsko rješenje kojim bi se poboljšao integritet izbornog procesa, Bosna i Hercegovina i dalje primjenjuje skup, zastarjeli sistem, koji je podložan manipulacijama i koji ne uživa povjerenje značajnog broja građana Bosne i Hercegovine. Šta više, uzimajući u obzir da su prioriteti političkih stranaka fokusirani na reforme koje se odnose na implementaciju presuda Evropskog suda za ljudska prava i odluke Ustavnog suda $\mathrm{BiH},{ }^{91}$ te da zanemaruju uvođenje novih tehnologija u izborni proces, čini se da će Bosna i Hercegovina i njeni građani još neko vrijeme biti uskraćena za jačanje integriteta tog procesa.

\section{Zaključak}

Bosna i Hercegovina je država koja je za trideset godina prešla put od prvih višestranačkih izbora, preko razarajućeg rata i suspenzije demokratskih izbora tokom tog perioda, potom izbora u organizaciji OSCE-a u uslovima u kojima se brojne protjerane osobe nisu mogle vratiti u svoja mjesta, do izbornog zakona koji je tokom proteklih 20 godina mijenjan isto toliko puta. Uzimajući u obzir sve te okolnosti, Izborni zakon BiH sadrži brojne napredne odredbe po kojim je Bosna i Hercegovina značajno ispred svojih susjeda, pa čak i nekih razvijenih demokratija. Istovremeno, Izborni zakon $\mathrm{BiH}$ - pored diskriminirajućih odredbi koje su dijelom i produkt bosanskohercegovačkog ustavnog uređenja - sadrži značajne anomalije, kako je u tekstu obrazloženo.

Kao zemlja koja je predala aplikaciju za članstvo u Evropskoj uniji, Bosna i Hercegovina ima jasnu pravnu obavezu da uskladi svoje izborno zakonodavstvo sa presudama Evropskog suda za ljudska prava i domaćih sudija, ali također treba unaprijediti to zakonodavstvo na drugim poljima kako bi se približila evropskoj demokratskoj praksi. S tim u vezi, te pogotovo ukoliko u ovom trenutku nema političke saglasnosti za izmjene koje zadiru u same temelje Daytonskog sporazuma, Bosna i Hercegovina treba raditi na ovim drugim izmjenama koje su opisane u ovom tekstu.

\footnotetext{
${ }^{90}$ Vidjeti, inter alia, https://www.klix.ba/vijesti/bih/cik-zbog-brojnih-nepravilnosti-ponistio-izbore-usrebrenici-i-doboju/210121035

${ }^{91}$ Vidjeti, inter alia, https://bhrt.ba/covic-i-izetbegovic-dogovorili-da-se-formiraju-radne-grupe-za-izborni-zakon-i-put-bih-ka-eu/
} 
Takve izmjene - poput jačanja demokratskog legitimiteta izabranih zvaničnika kroz drugi krug izbora, osiguravanja integriteta izbornog procesa kroz elektronsko brojanje glasova, uvođenja instituta vanrednih izbora kod situacija koje proizvode blokade, te podizanja izbornog cenzusa s ciljem smanjenja proliferacije političkih stranaka u svakako fragmentiranom političkom sistemu - bi značajno doprinijele stvaranju političke klime pogodne za kompleksnije i kontroverznije reforme izbornog zakonodavstva.

U odsustvu prevashodnog razmišljanja ove vrste među vodećim domaćim političkim elitama, međunarodna zajednica bi trebala zagovarati upravo ovakav pristup, ne samo s ciljem ispunjavanja formalnih uslova za članstvo u Evropskoj uniji kroz izvršenje presuda, već i radi jačanja izbornog kapaciteta onih političkih snaga koje se jasno zalažu za sprovedbu brojnih reformskih zakona, poput Zakona o sukobu interesa, te kompletne reforme pravosudnog sistema u Bosni i Hercegovini.

\section{Bibliografija:}

Centralna izborna komisija Bosne i Hercegovine, Rezultati izbora, http://www.izbori.ba

Robert A. Dahl, On Democracy (1998)

Dnevni list „Danas“،

Evropski sud za ljudska prava, Pilav v. Bosnia and Herzegovina,

Evropski sud za ljudska prava, Sejdic-Finci v. Bosnia and Herzegovina

Evropski sud za ljudska prava, Šlaku v. Bosnia and Herzegovina

Evropski sud za ljudska prava, Zornić v. Bosnia and Herzegovina

Evropski sud za ljudska prava, Yumak-Sadak v. Turkey

European Commission on Democracy through Law (Venice Commission), Report on Constituency Delineation and Seat Allocation, Study No. 873/2017

Bernard Grofman i Arend Lijphart (eds.), Electoral Laws \& Their Political Consequences (1986)

International Crisis Group, Is Dayton Falling (1999)

Izborni zakon Bosne i Hercegovine

Klix.ba

Parlamentarna skupština Bosne i Hercegovine, http://parlament.ba

Parlamentarna skupština Vijeća Evrope, Rezolucija 1547

Parlament Federacije BiH, https://predstavnickidom-pfbih.gov.ba

The Pew Center on the States, Inaccurate, Costly and Inefficient, Election Initiatives Issue Brief

Radio Sarajevo

Manfred G. Schmidt, Political performance and types of democracy: findings from comparative studies, European Journal of Political Research (2002)

Skupština Kantona Sarajevo, https://skupstina.ks.gov.ba

Ustav Bosne i Hercegovine

Ustav Federacije Bosne i Hercegovine

Ustav Republike Srpske 
Ustavni sud Bosne i Hercegovine, Odluka o dopustivosti i meritumu, U-23/14

Vrhovni sud SAD, Baker v. Carr

Vrhovni sud SAD, Reynolds v. Sims

Vrhovni sud SAD, Wesberry v. Sanders

\title{
Electoral System in Bosnia and Herzegovina: Hybrid Mixture of Modern and Outdated Solutions
}

\begin{abstract}
Summary
Bosnia and Herzegovina held its first multi-party elections in 1991, and faced a bloody and devastating war the following year. The Dayton Agreement brought peace at the end of 1995, and the first post-war elections were held in 1996, under the auspices of the OSCE. The Electoral Law was adopted by the Bosnia and Herzegovina Parliamentary Assembly in 2001, containing a number of modern, democratic features, such as a fully independent Central Election Commission with no ethnic or entity veto, mandatory gender representation on electoral rolls, automatic voter registration on the basis of ID rolls, and the like. At the same time, several Electoral Law provisions - mandated by Bosnia and Herzegovina's Daytonwrought Constitution were found contrary to the European Convention on Human Rights by the European Court in Strasbourg, while some others were declared unconstitutional by Bosnia and Herzegovina's Constitutional Court. These are highly politically-charged matters, resolution of which has been evasive for over a decade in some cases. In the meantime, due to the focus on these politically-sensitive priorities, Bosnia and Herzegovina's political elites have ignored changes that would dramatically improve legitimacy of elected officials through the introduction of run-off elections, strengthen the integrity of electoral process by way of electronic counting of ballots, as well as increase political stability through the raising of electoral threshold and the introduction of interim elections in situations of political deadlock that prevents government formation. The article discusses all of these matters, providing a comparative perspective, analysis and recommendations.
\end{abstract}

Key words: Early elections - Instant runoff - Electronic vote counting - Electoral threshold - Malapportionment 